\section{Cascade of care for people living with HIV infection in Southern Brazil: results from a public health network}

\author{
A cascata de cuidados para pessoas vivendo com \\ a infecção pelo HIV no Sul do Brasil: resultados \\ obtidos em uma rede pública de saúde
}

\section{Serie de cuidados para personas que viven con una infección de VIH en el sur de Brasil: resultados en una red pública de salud}

Ingridt Hildegard Vogler 1,2

Daniela Frizon Alfieri 1

Heloisa Damazio Bruna Gianjacomo 2

Elaine Regina Delicato de Almeida 1,2

Edna Maria Vissoci Reiche 1

\begin{abstract}
The cascade of care for people living with HIV infection (PLHIV) describes steps in diagnosis, linkage and retention in care, as well as the provision and success of combination antiretroviral therapy (cART). The aim of this study was to evaluate the rates regarding the retention in care, on cART, and suppressed viral load for PLHIV attended at a Brazilian public health network. Data on PLHIV from 116 cities of Paraná, Southern Brazil, attended from 2012 to 2015, were retrospectively collected through the Laboratory Tests Control System (SISCEL). The number of PLHIV related to care increased about 22.5\% from 2012 to 2015 (4,106 to 5,030 individuals). The proportion of PLHIV retained in care showed a trend toward stabilization around 81.786.9\%. Every year, the use of cART increased up to 90.3\% for PLHIV retained in care. Viral load suppression was achieved by $72.8 \%$ of patients on CART and $57.1 \%$ by those linked to care. Retention in care and HIV viral suppression were more likely to occur in older PLHIV than younger ones; similarly, patients living in medium-sized cities were more susceptible to these factors than in large-or small-sized cities. In conclusion, the study showed a high level of retention in care and HIV suppression on CART, as well as emphasized that current efforts for treating already-infected PLHIV remain a challenge for our health public institutions and may contribute to highlight steps for improvement of the HIV cascade of care in our population.
\end{abstract}

HIV; Highly Active Antiretroviral Therapy; Sustained Virologic Response doi: 10.1590/0102-311X00009718

\author{
Correspondence \\ E.M. V. Reiche \\ Departamento de Patologia, Análises Clínicas e Toxicológicas, \\ Centro de Ciências da Saúde, Universidade Estadual de \\ Londrina. \\ Av. Robert Koch 60, Londrina, PR 86038-440, Brasil. \\ reiche@sercomtel.com.br \\ ${ }_{1}^{1}$ Centro de Ciências da Saúde, Universidade Estadual de \\ Londrina, Londrina, Brasil. \\ 2 Hospital Universitário, Universidade Estadual de Londrina, \\ Londrina, Brasil.
}




\section{Introduction}

An important study found that the initiation on combination antiretroviral therapy (cART) in adults people living with HIV infection (PLHIV), i.e., with a CD4+ T cell count of more than 500 cells $/ \mu \mathrm{L}$, provided more benefits than therapy in patients with CD4+ T cell count at or lower than 350 cells/ $\mu \mathrm{L}$. The approach of initiating cART soon after diagnosis leads to reductions in serious AIDS-related events, such as development of cancers and opportunistic infections, as well as serious non-AIDSrelated events, as cardiovascular, renal and liver diseases and non-AIDS-defining cancers 1.

The cascade of care for PLHIV proposed currently encompasses five main steps: diagnosis, entry into care, retention in care, prescription of cART, and viral suppression 2. The ultimate goal of HIV treatment is to achieve the suppressed viral load so that the patient can stay healthy, live longer and with reduced chances of transmitting the infection to other people 3 . The models of the cascade of care differ in how the stages of HIV services required for a HIV-positive individual are outlined to achieve viral load suppression 4 . The steps are typically calculated in a conditional manner, with the number of persons completing the prior step serving as base population for the next step 5 . Differences in the construction of the cascade of care are common, some are prevalence-based and others are diagnosisbased; in the first case, each step represents a percentage of the total number of PLHIV diagnosed or not, and in the second case, only diagnosed cases are counted in the denominator 2.

The Joint United Nations Programme on HIV/AIDS (UNAIDS) has proposed the goal 90-90-90: An Ambitious Treatment Target to Help End the AIDS Epidemic, an approach in which it is expected that 90\% of all people with HIV infection should know the status of their infection, $90 \%$ of all people with diagnosed HIV infection should be consistently receiving cART and $90 \%$ of all people receiving cART should have a fully suppressed viral load 6. In 2017, the Department of Surveillance, Prevention, and Control of Sexually Transmitted Infection, HIV/AIDS and Viral Hepatitis (Departamento de Vigilância, Prevenção e Controle das Infecções Sexualmente Transmissíveis, do HIV/Aids e das Hepatites Virais) of the Brazilian Ministry of Health proposed a technical guideline to elaborate the continuum cascade of care for PLHIV and to be applied in the Brazilian states and municipalitites 7.

To our knowledge, information about the cascade of care for PLHIV in Paraná State is unknown. To address this issue, we aimed at evaluating the cascade of care considering the steps of retention in care, cART use, and viral load suppression in a cohort of PLHIV attended at the public health network in 116 municipalities of Paraná, Southern Brazil.

\section{Methods}

An observational retrospective study was carried out with all PLHIV outpatients, with medical request for CD4+ T cell count and/or HIV-1 viral load, attended at the Clinical Analysis Laboratory at the University Hospital of Londrina State University, Paraná State, from 2012 to 2015. These patients came from 116 cities of the North and part of the East macroregions of the Health Secretariat of Paraná, encompassing a total population of 2,770,115 inhabitants living in an area of $59,191 \mathrm{~km}^{2}$. This region has a total of 108 (93.1\%) cities classified as small ( $<50,000$ inhabitants), four (3.4\%) as medium (50,000-100,000 inhabitants) and other four (3.4\%) as large (> 100,000 inhabitants) 8 .

Data were obtained by consulting the Laboratory Tests Control System (SISCEL - Sistema de Controle de Exames Laboratoriais), an online application developed by the Brazilian Ministry of Health for management of both CD4+ T cell count and HIV-1 viral load. The study was conducted in accordance with the Declaration of Helsinki and approved by the local Ethics Research Committee, granted under the n. 1053745/2015 (CAAE 44127215.0.0000.5231). Considering that the study was based on a query in a database, an informed consent was not obtained from patients; however, to guarantee the confidentiality, patient record/data prior to analysis were consecutively identified by number.

Sample was obtained consecutively, in convenience of time and location, and consisted of sociodemographic variables, laboratory biomarkers, and therapeutic information of PLHIV that were at the laboratory and clinical monitoring of HIV-1 infection. To ensure information reliability, data from 
the PLHIV were checked in two queries by the system and all duplicate records were removed. Individuals registered on SISCEL database, in use or not of cART, and that performed HIV-1 viral load and/or CD4+ T cell count during the study period were included. Patients who carried out HIV-1 viral load for diagnostic purposes and obtained undetectable results were excluded from the study.

The study had a longitudinal (from 2012 to 2015) and a cross-sectional design (2015). Variables of interest were verified for each year (2012-2015). Subjects were categorized as being "linked to care" from the date of the first reported CD4+ T cell count or HIV-1 viral load registered in SISCEL. The presence of any CD4+ T cell count or HIV-1 viral load report was used to indicate a clinical care episode. PLHIV were categorized as "retained in care" if they had been seen in at least one visit in that year. The individual was considered as being "on cART" as soon as the SISCEL system registered the beginning of the therapy, even if adherence was unknown. PLHIV was defined as having "suppressed viral load" or suppression of HIV infection if they showed a viral load value of less than 50 copies $/ \mathrm{mL}$ verified for each year. This viral load threshold was considered due to the sensitivity of the reagent set provided by the Brazilian public network during the period of the study, as branched-DNA (bDNA, Versant HIV-1 RNA 3.0 Assay, Siemens Healthcare, USA), with lower detection limit of 50 copies $/ \mathrm{mL}$, and quantitative polymerase chain reaction (qPCR, Abbott Real Time HIV-1, Abbott Molecular Inc., USA), with lower detection limit of 40 copies $/ \mathrm{mL}$. Patients with no laboratory attendances in the last two years of the study were excluded of the linkage to care and absences from follow-up sections were considered as due to death or migration 9,10 .

\section{Statistical analysis}

Data were analyzed through the IBM SPSS program, version 20 (https://www.ibm.com/). The median and interquartile range (IQR) of $25 \%$ and $75 \%$ were calculated for each continuous variable. Sociodemographic characteristics were categorized and described as absolute number (n) and relative frequency (\%), and were compared by chi-square test $\left(\chi^{2}\right)$. Logistic binary regression was performed to obtain unadjusted and adjusted odds ratio (OR) and 95\% confidence interval (95\%CI) for factors associated with retention in care, use of cART and viral load suppression. Variables included in the analysis were sex, age, ethnicity, educational level, size of the municipality of living and time since diagnosis. Results were considered significant when $\mathrm{p}$-value was less than $0.05(\mathrm{p}<0.05)$.

\section{Results}

\section{Period from 2012 to 2015}

A total of 4,106, 4,651, 4,876 and 5,030 patients were linked to care from 2012 to 2015, respectively. Although the number of patients linked to care increased over the time, the proportion of patients retained in care became stable during this period $(\mathrm{p}=0.387)$. The frequencies of patients on cART and with viral load suppression increased over the time, even when calculated for the total of patients both linked to or retained in care $(\mathrm{p}<0.001)$. However, annual rates of suppressed viral load among patients on cART were $71.8 \%, 66.4 \%, 68.2 \%$ and $72.8 \%$ from 2012 to 2015 , respectively, indicating a trend of stabilization for these frequencies $(\mathrm{p}=0.426)$ (Table 1$)$.

\section{Cascade of care in 2015}

In 2015, 5,030 PLHIV in our jurisdiction were linked to care. A cascade of care for male and female individuals was constructed, and results showed that female patients had greater frequency of retention in care $(\mathrm{p}=0.001)$, cART use $(\mathrm{p}<0.001)$ and suppressed viral load $(\mathrm{p}<0.001)$ when compared to male patients. When the prior step of the cascade of care was used as the denominator of the next step, cART use showed a higher frequency in women when compared to man ( $<0.001)$; moreover, the suppressed viral load was lower in female patients than in male ones, but the difference was not statistically significant $(\mathrm{p}=0.469)$, as shown in Figure 1 . 
Table 1

Cascade of care for people living with HIV infection from 2012 to 2015.

\begin{tabular}{|c|c|c|c|c|c|}
\hline Steps of the cascade & $\begin{array}{l}2012 \\
\text { n (\%) }\end{array}$ & $\begin{array}{l}2013 \\
\text { n (\%) }\end{array}$ & $\begin{array}{l}2014 \\
\text { n (\%) }\end{array}$ & $\begin{array}{l}2015 \\
\text { n (\%) }\end{array}$ & p-value \\
\hline Linked to care * & $4,106(100.0)$ & $4,651(100.0)$ & $4,876(100.0)$ & $5,030(100.0)$ & \\
\hline Retained in care & $3,525(85.8)$ & $3,801(81.7)$ & $4,133(84.8)$ & $4,371(86.9)$ & 0.387 \\
\hline On CART & $2,872(69.9)$ & $3,184(68.5)$ & $3,599(73.8)$ & $3,946(78.4)$ & $<0.001 * *$ \\
\hline Suppressed viral load $* * *$ & $2,062(50.2)$ & $2,115(45.5)$ & $2,455(50.3)$ & $2,871(57.1)$ & $<0.001 * *$ \\
\hline Retained in care * & $3,525(100.0)$ & $3,801(100.0)$ & $4,133(100.0)$ & $4,371(100.0)$ & \\
\hline On cART & $2,872(81.5)$ & $3,184(83.8)$ & $3,599(87.1)$ & $3,946(90.3)$ & $<0.001 *$ \\
\hline Suppressed viral load *** & $2,062(58.5)$ & $2,115(55.6)$ & $2,455(59.4)$ & $2,871(65.7)$ & $<0.001 *$ \\
\hline On CART * & $2,872(100.0)$ & $3,184(100.0)$ & $3,599(100.0)$ & $3,946(100.0)$ & \\
\hline Suppressed viral load $* \star \star$ & $2,062(71.8)$ & $2,115(66.4)$ & $2,455(68.2)$ & $2,871(72.8)$ & 0.426 \\
\hline
\end{tabular}

CART: combination antiretroviral therapy.

* Step of the cascade used as denominator for the next steps;

** $\chi^{2}$ for trend;

*** HIV-1 viral load with lower limit of detection of 50 copies $/ \mathrm{mL}$ or $1.70 \log _{10}$ copies $/ \mathrm{mL}$.

Figure 1

Cross-sectional cascade of care for male and female people living with HIV infection in 116 cities of Paraná State, Brazil, in 2015.

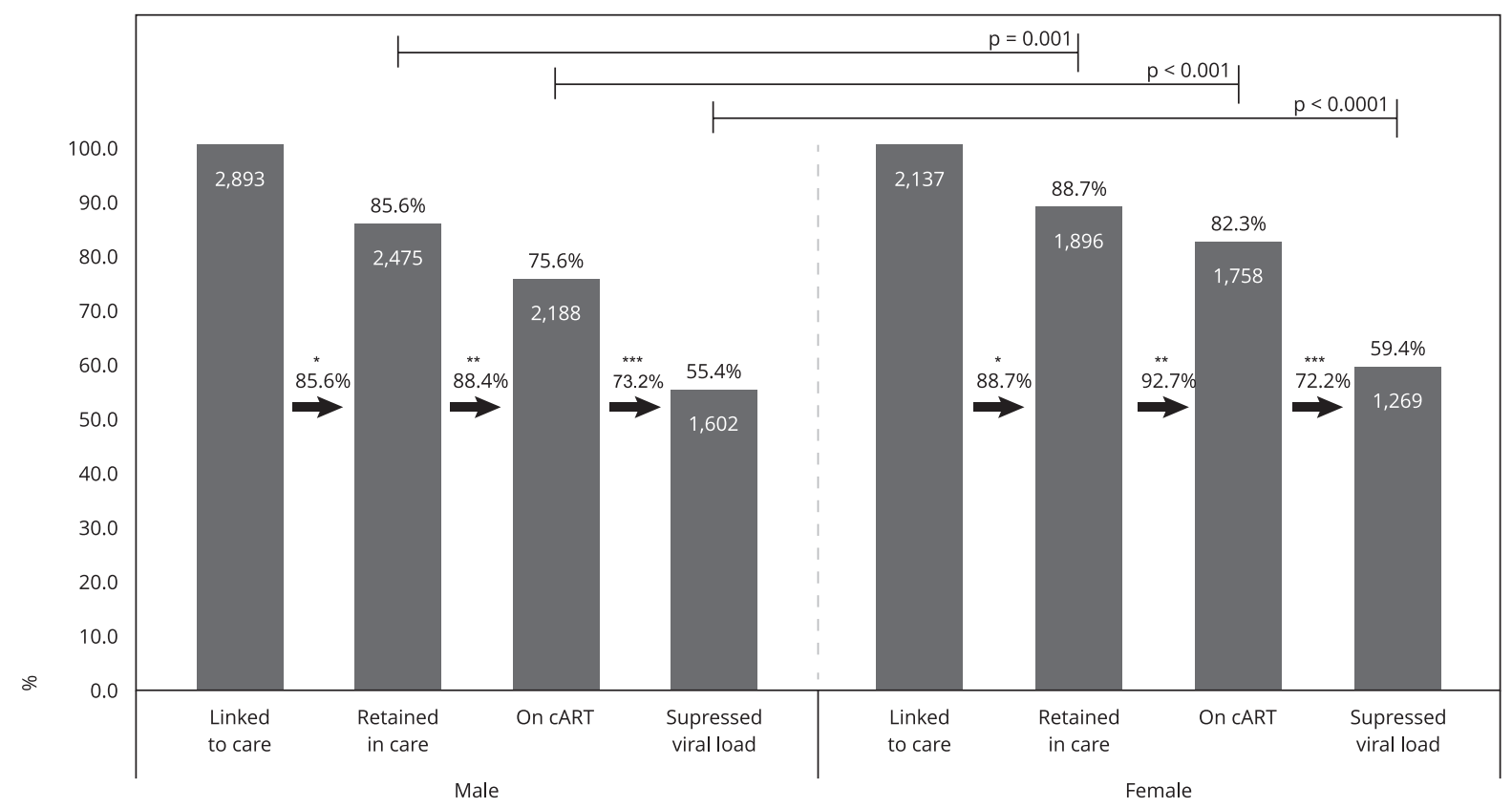

CART: combination antiretroviral therapy.

$* p=0.001$;

$* \star p<0.001$

$\star \star * \mathrm{p}=0.469$. 


\section{Sociodemographic characteristics in 2015}

In 2015, the median age of PLHIV linked to care was 39.5 years (IQR: 31.3-48.6), the median time since diagnosis was 6.1 years (IQR: 2.0-11.3) and the median time on cART was 4.8 years (IQR: 1.810.0). Most of the PLHIV were men (57.5\%), Caucasians (74.2\%), with less than 12 years of education (81.5\%) and living in large-sized cities (59\%), as shown in Table 2. Sociodemographic variables were relevant to evaluate the cascade of care according to the steps of retention in care, cART use, and viral load suppression. We found that frequencies of retention in care were significantly higher in women, individuals diagnosed for over 10 years, patients on cART for over 15 years, and was significantly lower in patients aged between 30-39, when compared to older ones. PLHIV on cART use were more likely to be women, with less than 12 years of education, living more in medium-sized when compared to large-sized ones, and diagnosed for over five years. The use of cART showed small frequencies in younger adults from 15 to 39 years when compared to the patients aged $\geq 50$ years. Suppressed viral load was significantly higher in females, aged $\geq 50$ years, Caucasians, living more in mediumsized cities when compared to large-sized ones, and in those diagnosed for over five years (Table 2).

\section{Logistic binary regression}

All variables were analyzed in logistic regression according to male patients, older (> 50 years), Caucasians, well educated ( $>12$ years of education), living in large-sized municipalities and recently being diagnosed with HIV-1 (0-4 years) as the reference group. Results showed that individuals that are female $(\mathrm{OR}=1.29$; 95\%CI: 1.08-1.54; $\mathrm{p}=0.004)$, living in medium-sized cities $(\mathrm{OR}=1.36$; $95 \% \mathrm{CI}$ : $1.02-1.80 ; \mathrm{p}=0.037)$ and being diagnosed for more than 15 years $(\mathrm{OR}=1.61 ; 95 \% \mathrm{CI}: 1.15-2.25 ; \mathrm{p}=$ $0.005)$ are more likely to be retained in care. In addition, those aged between 30 and 39 years $(\mathrm{OR}=$ 0.72; 95\%CI: 0.57-0.92; $\mathrm{p}=0.009)$, and having no education $(\mathrm{OR}=0.56$; 95\%CI: 0.33-0.96; $\mathrm{p}=0.034)$ have a lower chance of being retained in care. Individuals with no education $(\mathrm{OR}=4.03$; 95\%CI: $1.26-$ 12.88; $\mathrm{p}=0.019)$ and those who have studied for 8 - 11 years $(\mathrm{OR}=1.41 ; 95 \% \mathrm{CI}$ : $1.03-1.92 ; \mathrm{p}=0.030)$, living in small-sized $(\mathrm{OR}=1.39$; 95\%CI: $1.08-1.80 ; \mathrm{p}=0.012)$ and medium-sized cities $(\mathrm{OR}=1.66$; 95\%CI: 1.14-2.41; $\mathrm{p}=0.008$ ) and those being diagnosed for more than five years are more likely to be on cART use. However, those aged between 15 and 29 years $(\mathrm{OR}=0.45$; 95\%CI: 0.31-0.63; $\mathrm{p}<0.001)$ have less chance of being on cART. Inhabitants of medium-sized cities (OR = 1.30; 95\%CI: 1.03-1.64; $\mathrm{p}=0.026$ ) have a higher chance of suppressed viral load. In all age groups, being non-Caucasian $(\mathrm{OR}=0.71 ; 95 \% \mathrm{CI}: 0.61-0.84 ; \mathrm{p}<0.001)$ and at any educational level indicate a lower chance of viral load suppression (Table 3).

\section{Discussion}

In this research, a PLHIV population in the public health network of Paraná State, was monitored according to laboratory parameters. Our objective was to evaluate the proportion of PLHIV that were successful in some steps of the cascade of care, analyzed in a longitudinal and cross-sectional design.

In the longitudinal design, data from 2012 to 2015 were analyzed and we verified that the number of PLHIV linked to care increased 22.5\% over the time (from 4,106 to 5,030 individuals), indicating that HIV-infection and/or diagnosis are increasing. The proportion of individuals retained in care showed a trend toward stabilization of $85.8-86.9 \%$ in this period. The use of cART increased continuously from 2012 to 2015 , and reached $90.3 \%$ among those retained in care in 2015 . In that year, the rate of suppressed viral load was $72.8 \%$ for those on cART and $57.1 \%$ among the overall population in care. These results are in agreement with those reported in developed countries, such as Canada, where the proportions of patients retained in care that experienced cART and had the HIV infection suppressed were of $88 \%$ and $76 \%$, respectively 11 , and United States, where the rates of patients retained in care (on cART) and that achieved viral suppression were $89 \%$ and 77\%, respectively 12 .

To increase the proportion of PLHIV who have suppressed viral load is the goal of any HIV treatment program. Our results demonstrate that the 90-90-90: An Ambitious Treatment Target to Help End the AIDS Epidemic 6 goal has not been fully reached yet. However, some important considerations must 
Table 2

Cascade of care for the steps of retention in care, use of combination antiretroviral therapy (CART) and suppressed viral load, stratified according to sociodemographic characteristics of patients infected with human immunodeficiency virus type 1 (HIV-1), evaluated in 2015.

\begin{tabular}{|c|c|c|c|c|}
\hline \multirow[t]{2}{*}{ Variables } & \multicolumn{4}{|c|}{ Patients linked to care } \\
\hline & $\begin{array}{c}\text { Total } \\
\text { (Column \%) }\end{array}$ & $\begin{array}{l}\text { Retained in care } \\
\text { (Row \%) }\end{array}$ & $\begin{array}{l}\text { On CART } \\
\text { (Row \%) }\end{array}$ & $\begin{array}{l}\text { Suppressed viral load * } \\
\text { (Row \%) }\end{array}$ \\
\hline Total & $5,030(100.0)$ & $4,371(86.9)$ & $3,946(78.4)$ & $2,871(57.1)$ \\
\hline \multicolumn{5}{|l|}{ Sex } \\
\hline Female & $2,137(42.5)$ & $1,896(88.7)$ ** & $1,758(82.3)$ ** & $1,269(59.4) * *$ \\
\hline Male & $2,893(57.5)$ & $2,475(85.6) * * \star$ & $2,188(75.6) * * \star$ & $1,602(55.4) * * *$ \\
\hline \multicolumn{5}{|l|}{ Age (years) } \\
\hline $0-14$ & $88(1.7)$ & $80(90.9)$ & $77(87.5)$ & $50(56.8) * \star$ \\
\hline $15-29$ & $941(18.7)$ & $811(86.2)$ & $643(68.3) * \star$ & $405(43.0) * *$ \\
\hline $30-39$ & $1,483(29.5)$ & $1,259(84.9) * *$ & $1,143(77.1)^{* *}$ & $778(52.5)$ ** \\
\hline $40-49$ & $1,372(27.3)$ & $1,207(88.0)$ & $1,128(82.2)$ & $841(61.3)$ ** \\
\hline $50-90$ & $1,146(22.8)$ & $1,014(88.5) * * *$ & $955(83.3) * * *$ & $797(69.5) * * *$ \\
\hline Median (IQR) \# & $39.5(31.3-48.6)$ & & & \\
\hline \multicolumn{5}{|l|}{ Ethnicity } \\
\hline Caucasian & $3,732(74.2)$ & $3,258(87.3) * * *$ & $2,937(78.7) * * *$ & $2,198(58.9) * * *$ \\
\hline Non-Caucasian & $1,298(25.8)$ & $1,113(85.7)$ & 1,009 (77.7) & $673(51.8) * *$ \\
\hline \multicolumn{5}{|c|}{ Educational level (years) } \\
\hline None & $143(2.8)$ & $119(83.2)$ & $115(80.4)$ & $82(57.3)$ \\
\hline $1-3$ & $570(11.3)$ & $503(88.2)$ & $463(81.2) * *$ & $324(56.8)$ \\
\hline $4-7$ & $1,865(37.1)$ & $1,628(87.3)$ & $1,506(80.8) * *$ & $1,090(58.4)$ \\
\hline 8-11 & $1,525(30.3)$ & 1,353 (88.7) & $1,226(80.4) * *$ & $892(58.5)$ \\
\hline$\geq 12$ & $726(14.4)$ & $634(87.3) * * *$ & $542(74.7) * * \star$ & $423(58.3) * * *$ \\
\hline Not known & $201(4.0)$ & & & \\
\hline \multicolumn{5}{|c|}{ Municipality of living \#\# } \\
\hline Small-sized & $1,461(29.0)$ & $1,260(86.2)$ & $1,145(78.4)$ & $806(55.2)$ \\
\hline Medium-sized & $603(12.0)$ & $540(89.6)$ & $502(83.3) * *$ & $384(63.7) * *$ \\
\hline Large-sized & $2,966(59.0)$ & $2,571(86.7) * * *$ & $2,299(77.5) * * *$ & $1,681(56.7) * * *$ \\
\hline \multicolumn{5}{|c|}{ Time of HIV infection diagnosis (years) } \\
\hline $0-4$ & $2,218(44.1)$ & $1,895(85.4) * * *$ & $1,510(68.1) * * \star$ & $1,074(48.4) * * *$ \\
\hline $5-9$ & $1,250(24.9)$ & $1,075(86.0)$ & $1,047(83.8) * *$ & $767(61.4) * *$ \\
\hline $10-14$ & $999(19.9)$ & $885(88.6) * *$ & $875(87.6) * *$ & $639(64.0) * *$ \\
\hline$\geq 15$ & $563(11.2)$ & $516(91.7)$ ** & $514(91.3) * *$ & $391(69.4)$ ** \\
\hline Median (IQR) \# & $6.1(2.0-11.3)$ & & & \\
\hline \multicolumn{5}{|c|}{ Time on CART (years) } \\
\hline $0-4$ & $2,273(45.2)$ & $1,999(87.9) * * \star$ & $1,999(87.9) * \star \star$ & $1,403(61.7) * * *$ \\
\hline $5-9$ & $1,058(21.0)$ & $944(89.2)$ & $944(89.2)$ & $711(67.2) * *$ \\
\hline $10-14$ & $715(14.2)$ & $624(87.3)$ & $624(87.3)$ & $456(63.8)$ \\
\hline$\geq 15$ & $405(8.1)$ & 379 (93.6) ** & 379 (93.6) & $301(74.3)$ ** \\
\hline Naive & $579(11.5)$ & 425 (73.4) & $0(0.0)$ & $0(0.0)$ \\
\hline Median (IQR) \# & $4.8(1.8-10.0)$ & & & \\
\hline
\end{tabular}

CART: combination antiretroviral therapy.

* HIV-1 viral load with lower detection limit of 50 copies $/ \mathrm{mL}$ or $1.70 \log _{10}$ copies $/ \mathrm{mL}$;

** $\mathrm{p}<0.05$ based on reference category for each variable;

*** Reference category;

\# Values expressed as median and interquartile range (IQR) of $25 \%$ and $75 \%$;

\#\# Municipality: small-sized (<50,000 inhabitants); medium-sized (50-100,000 inhabitants); large-sized (> 100,000 inhabitants). 
Table 3

Logistic binary regression for variables associated with retention in care, combination antiretroviral therapy (cART) use and suppressed viral load in people living with HIV linked to care, from Paraná State, Brazil, in 2015.

\begin{tabular}{|c|c|c|c|c|c|c|}
\hline \multirow[t]{2}{*}{ Variables } & \multicolumn{2}{|c|}{ Retained in care } & \multicolumn{2}{|c|}{ On CART } & \multicolumn{2}{|c|}{ Suppressed viral load * } \\
\hline & $\begin{array}{l}\text { OR adjusted } \\
\qquad(95 \% \mathrm{Cl})\end{array}$ & p-value & $\begin{array}{l}\text { OR adjusted } \\
\qquad(95 \% \mathrm{Cl})\end{array}$ & p-value & $\begin{array}{l}\text { OR adjusted } \\
\qquad(95 \% \mathrm{Cl})\end{array}$ & p-value \\
\hline \multicolumn{7}{|l|}{ Sex } \\
\hline Female & $1,29(1.08-1.54)$ & 0.004 & $1.11(0.88-1.40)$ & 0.387 & $1.00(0.86-1.16)$ & 0.992 \\
\hline Male & 1.00 & & 1.00 & & 1.00 & \\
\hline \multicolumn{7}{|l|}{ Age (years) } \\
\hline $0-14$ & $1.50(0.68-3.29)$ & 0.314 & $0.62(0.16-2.37)$ & 0.483 & $0.41(0.24-0.70)$ & 0.001 \\
\hline $15-29$ & $0.83(0.63-1.09)$ & 0.187 & $0.45(0.31-0.63)$ & $<0.001$ & $0.29(0.23-0.38)$ & $<0.001$ \\
\hline $30-39$ & $0.72(0.57-0.92)$ & 0.009 & $0.73(0.52-1.05)$ & 0.088 & $0.39(0.31-0.49)$ & $<0.001$ \\
\hline $40-49$ & $0.94(0.74-1.21)$ & 0.644 & $0.83(0.57-1.21)$ & 0.327 & $0.57(0.46-0.71)$ & $<0.001$ \\
\hline $50-90$ & 1.00 & & 1.00 & & 1.00 & \\
\hline \multicolumn{7}{|l|}{ Ethnicity } \\
\hline Caucasian & 1.00 & & 1.00 & & 1.00 & \\
\hline Non-Caucasian & $0.91(0.75-1.09)$ & 0.298 & $1.14(0.89-1.47)$ & 0.303 & $0.71(0.61-0.84)$ & $<0.001$ \\
\hline \multicolumn{7}{|c|}{ Educational level (years) } \\
\hline None & $0.56(0.33-0.96)$ & 0.034 & $4.03(1.26-12.88)$ & 0.019 & $0.58(0.35-0.95)$ & 0.032 \\
\hline $1-3$ & $0.91(0.64-1.30)$ & 0.612 & $1.06(0.68-1.65)$ & 0.788 & $0.52(0.38-0.70)$ & $<0.001$ \\
\hline $4-7$ & $0.87(0.67-1.14)$ & 0.323 & $1.12(0.81-1.54)$ & 0.494 & $0.65(0.51-0.82)$ & $<0.001$ \\
\hline $8-11$ & $1.09(0.83-1.43)$ & 0.550 & $1.41(1.03-1.92)$ & 0.030 & $0.74(0.58-0.94)$ & 0.016 \\
\hline$\geq 12$ & 1.00 & & 1.00 & & 1.00 & \\
\hline \multicolumn{7}{|c|}{ Municipality of living ** } \\
\hline Small-sized & $1.09(0.90-1.31)$ & 0.396 & $1.39(1.08-1.80)$ & 0.012 & $0.94(0.80-1.11)$ & 0.458 \\
\hline Medium-sized & $1.36(1.02-1.80)$ & 0.037 & $1.66(1.14-2.41)$ & 0.008 & $1.30(1.03-1.64)$ & 0.026 \\
\hline Large-sized & 1.00 & & 1.00 & & 1.00 & \\
\hline \multicolumn{7}{|c|}{ Time of diagnosis (years) } \\
\hline $0-4$ & 1.00 & & 1.00 & & 1.00 & \\
\hline $5-9$ & $0.94(0.76-1.16)$ & 0.563 & $8.13(5.47-12.11)$ & $<0.001$ & $1.00(0.83-1.20)$ & 0.985 \\
\hline $10-14$ & $1.23(0.96-1.56)$ & 0.095 & $19.64(10.34-37.32)$ & $<0.001$ & $0.95(0.78-1.16)$ & 0.637 \\
\hline$\geq 15$ & $1.61(1.15-2.25)$ & 0.005 & $54.62(13.48-221.30)$ & $<0.001$ & $0.95(0.74-1.21)$ & 0.663 \\
\hline
\end{tabular}

95\% Cl: 95\% confidence interval; cART: combination antiretroviral therapy.

* HIV-1 viral load with lower detection limit of 50 copies $/ \mathrm{mL}$ or $1.70 \log _{10} \mathrm{copies} / \mathrm{mL}$;

** Municipality: small-sized (<50,000 inhabitants); medium-sized (50-100,000 inhabitants); large-sized (> 100,000 inhabitants).

be highlighted about these results. First, the proportion of patients diagnosed with HIV-1 infection in our jurisdiction could not be defined; therefore, our data of PLHIV in care represent only patients diagnosed with HIV-1 infection and that looked for a public health service to manage this infection. Second, the increase in the rates of PLHIV on cART is substantial, but refers only to individuals under clinical and laboratory care. Third, the definition of suppressed viral load used for our research was below 50 copies/mL, unlike other studies 3,10,13. Even with a lower threshold, our result for suppressed viral load was similar to the previously reported rate of $77.1 \%$ for individuals on cART in Brazil, but with a viral load cut-off point below 400 copies/mL 14 .

In our cross-sectional analysis, only data from 2015 (last year of the study) were used for sociodemographic characterization of the population in the steps of the cascade of care. Some variables showed expected results as described elsewhere, such as that females and patients older than 50 were more likely to be retained in care, as well as Caucasians and older people had better viral load 
suppression 3,10,15. Disparities in the HIV-1 cascade were highlighted in an American study that found smaller rates of linkage to care, retention in care and viral load suppression for adolescents and young adults when compared to older adults 16 .

About education level, when all ranges were compared to that for $>12$ years of education, we found worst retention in care for patients without education and worst viral load suppression for all educational levels. These findings were in agreement with other studies that associate better educational level with more retention in care, as well as with more adherence to therapy 17,18. However, in our study, an unexpected significant positive association was found between non-educated patients using cART; this fact cannot be explained, but we believe that these individuals are economically disadvantaged and completely dependent on public services; therefore, they seek access to therapy in order to remain linked to the system, even with poor adherence and bad viral suppression rates, because they know how difficult it is to return to the system after abandoning it.

In our study, results showed that PLHIV diagnosed for $>15$ years were more likely to be retained in care, as well as the chance of having to use cART increased proportionally in accordance with the time of diagnosis. HIV diagnosis for over than 10 years and undetectable viral load were previously associated with higher levels of adherence 18. However, time of diagnosis and viral load suppression were not associated in our patients, indicating that adherence must be more encouraged to improve viral suppression rates in our population.

Compared to large-sized cities, individuals living in those of medium and small sizes showed greater chance of being on cART; also, retention in care and viral load suppression were more likely to occur for those living in medium-sized cities. Cities with less than 100,000 inhabitants represent around $97 \%$ of all municipalities analyzed in this study and $41 \%$ of our patients lived in these locations. Cities with less than 50,000 inhabitants do not usually have secondary (specialized outpatient) or tertiary (hospitals) healthcare provision and require support from the Regional Health Institution, defined as a group of adjacent municipalities attended by units for primary, emergency and psychosocial health care, specialized outpatient care, inpatient care, and disease surveillance services ${ }^{19}$. Percentages of treated patients with undetectable viral load were previously found to be lower in Brazil's less developed regions 14 . In our study, unexpected better results were found especially for individuals living in medium-sized municipalities.

The improvement of cascade of care is a challenge everywhere. Optimal outcomes along this cascade for PLHIV have not been achieved even in the United States, where among all PLHIV, about $86 \%$ had been diagnosed with HIV infection, $40 \%$ were engaged in medical care, $37 \%$ were on cART, and only $30 \%$ had suppressed viral load 20. The Brazilian model was constructed by adapting the measures to the availability of national data, and it is supposed that about $83 \%$ of PLHIV are diagnosed, $80 \%$ linked to care, $66 \%$ retained in care, $52 \%$ on cART use and $46 \%$ with suppressed viral load 21

We should not compare our data to the national cascade of care of Brazil, because the number of PLHIV in our jurisdiction cannot be guaranteed. The Brazilian Ministry of Health estimates that $0.39 \%$ of the entire population is infected with HIV 21. This would represent about 10,000 PLHIV at our region; however, this number does not take into account probable differences in rates from largeand small-sized cities 22,23 . If we consider this number, it evidences that half of this population was evaluated by our study, which could mean low rates for diagnosis of HIV infection, PLHIV in care in the private network, or both 24. It is believed that only $24 \%$ of the Brazilian population have private health insurance 19 .

A systematic review identified significant variability in the proposed models for cascade of care for PLHIV. The models describe differences in the number of steps delineated, definitions used to delineate both numerators and denominators at each of the steps, attendance requirements used in defining linkage to care or CART use, as well as what cut-off point constituted viral load suppression 13 . These models usually show the results with a bar graph, in which each bar represents the proportion of persons completing each step 2,25. If the denominator is kept constant throughout sequential steps, the overall impact of cumulative losses is visually more apparent. If the numerator in the first step is taken as the denominator of the subsequent step, each step is essentially represented as a separate event and the impact of cumulative losses through sequential steps is visually de-emphasized 26 . Some studies represent these two approaches together, probably because they provide better information about the healthcare process, especially for viral load 
suppression 27,28. For example, in a study with HIV-positive sex workers in Cambodia, viral suppression was obtained only for $23 \%$ of the diagnosed HIV-positive women in the cohort, but this proportion increased to $59 \%$ when considering female patients that were in care for the last 12 months 28 . In India, 31\% of the diagnosed patients and 82\% of patients who used cART achieved viral suppression 29. In a public hospital in Buenos Aires, Argentina, virologic suppression was obtained in $31 \%$ of patients linked to care, and 59\% of those were on cART 27. As in our research, this last study evaluated their cohort considering the proportions of individuals linked to care, and not the total number of diagnosed cases.

We are conscious about an important study limitation with regard to the number of PLHIV linked to care. Patients may be not retained in care in our jurisdiction due to migration or death. In our longitudinal analyses, PLHIV were removed from the denominator after 2 years without HIVrelated laboratory tests, supposing that they had migrated or were dead. It is possible that we could have excluded incorrectly some patients who did not attend adequately the outpatient care, but it was beyond our control. Failure to remove patients who died or migrated would overestimate the number of linked patients in the denominator, resulting in underestimated proportions of patients retained in care, on cART use and with suppressed viral load 10.

Data on the routine monitoring of patients had great utility for assessment of the population health; therefore, the effectiveness of the cART program must be continuously evaluated. Reported laboratory data are useful to achieve this goal, easy to collect, as well as reliable and scalable from a single clinic to an entire population 30 . We recognize that the retrospective design of our analysis and the absence of certain data, as adherence to therapy for individuals analyzed, proportion of individuals diagnosed and undiagnosed at our region, as well as proportion of lost during the follow-up period due to death or migration, are some limitations of this study. However, we were able to identify some sociodemographic features, associated with HIV care in a public health service with widespread access to cART, that could influence the success in different steps of the cascade of care.

When considered together, the results of this study showed a high level of retention in care and effective HIV suppression due to cART. The results emphasize the steps for improvement of the HIV-1 cascade of care in our population, including more attention to male, non-Caucasian, younger, less educated and recently diagnosed adults. New approaches must be implemented for these groups so patient retention in the service and commitment to treatment can be ensured, and thus the 90-90-90: An Ambitious Treatment Target to Help End the AIDS Epidemic goal proposed by UNAIDS can be achieved. 


\section{Contributors}

I. H. Vogler and E. M. V. Reiche made substantial contributions to study conception and design, data acquisition, analysis and interpretation; drafting and critical revision of the article for important intellectual content; and final approval of the version for publication. D. F. Alfieri participated in data acquisition, analysis and interpretation, and final approval of the version for publication. H. D. B. Gianjacomo participated in laboratory tests and final approval of the version for publication. E. R. D. Almeida participated in the critical revision and final approval of the version for publication.

\section{References}

1. INSIGHT START Study Group; Lundgren JD, Babiker AG, Gordin F, Emery S, Grund B, et al. Initiation of antiretroviral therapy in early asymptomatic HIV infection. N Engl J Med 2015; 373:795-807.

2. Centers for Disease Control and Prevention. Understanding the HIV care continuum. https://www.cdc.gov/hiv/pdf/library/fact sheets/cdc-hiv-care-continuum.pdf (accessed on 17/Aug/2017).

3. Horberg MA, Hurley LB, Klein DB, Towner WJ, Kadlecik P, Antoniskis D, et al. The HIV care cascade measured over time and by age, sex, and race in a large national integrated care system. AIDS Patient Care STDS 2015; 29:582-90.

4. MacCarthy S, Hoffmann M, Ferguson L, Nunn A, Irvin R, Bangsberg D, et al. The HIV care cascade: models, measures and moving forward. J Int AIDS Soc 2015; 18:e19395.

5. Yehia BR, Stephens-Shields AJ, Fleishman JA, Berry SA, Agwu AL, Metlay JP, et al. The HIV care continuum: changes over time in retention in care and viral suppression. PLoS One 2015; 10:e0129376.

6. Joint United Nations Programme on HIV/ AIDS. 90-90-90: an ambitious treatment target to help end the AIDS epidemic. http:// www.unaids.org/en/resources/documents/ 2017/90-90-90 (accessed on 27/Aug/2017).

7. Departamento de Vigilância, Prevenção e Controle das Infecções Sexualmente Transmissíveis, do HIV/ Aids e das Hepatites Virais, Secretaria de Vigilância em Saúde, Ministério da Saúde. Manual técnico de elaboração da cascata de cuidado contínuo do HIV. Brasília: Ministério da Saúde; 2017.

8. Costa NR. The Family Health Strategy: primary health care and the challenge of Brazilian metropolises. Ciênc Saúde Coletiva 2016; 21:1389-98.

9. Althoff KN, Buchacz K, Hall HI, Zhang J, Hanna DB, Rebeiro P, et al. US trends in antiretroviral therapy use, HIV RNA plasma viral loads, and CD4 T-lymphocyte cell counts among HIV-infected persons, 2000 to 2008. Ann Intern Med 2012; 157:325-35.

10. Torian LV, Xia Q, Wiewel EW. Retention in care and viral suppression among persons living with HIV/AIDS in New York City, 20062010. Am J Public Health 2014; 104:e24-9.

11. Krentz HB, MacDonald J, Gill MJ. High mortality among human immunodeficiency virus (HIV)-infected individuals before accessing or linking to HIV care: a missing outcome in the cascade of care? Open Forum Infect Dis 2014; 1:ofu011.

12. Centers for Disease Control and Prevention. Vital signs: HIV prevention through care and treatment - United States. MMWR Morb Mortal Wkly Rep 2011; 60:1618-23. 
13. Medland NA, McMahon JH, Chow EPF, Elliott JH, Hoy JF, Fairley CK. The HIV care cascade: a systematic review of data sources, methodology and comparability. J Int AIDS Soc 2015; 18:e20634.

14. Diaz RS, Inocêncio LA, Sucupira MCA, Pereira AA, Hunter J, Ferreira JE, et al. The virological and immunological characteristics of the HIV1 -infected population in Brazil: from initial diagnosis to impact of antiretroviral use. PLoS One 2015; 10:e0139677.

15. Dehghani Firouzabadi A, McDonald TC, Samms TR, Sirous R, Johnson K. Disparities in HIV clinical outcomes among a cohort of HIVinfected persons receiving care-Mississippi. Int J Environ Res Public Health 2017; 14:e392.

16. Zanoni BC, Mayer KH. The adolescent and young adult HIV cascade of care in the United States: exaggerated health disparities. AIDS Patient Care STDS 2014; 28:128-35.

17. Silva DS, DeBoni RB, Lake JE, Cardoso SW, Ribeiro S, Moreira RI, et al. Retention in early care at an HIV outpatient clinic in Rio de Janeiro, Brazil, 2000-2013. AIDS Behav 2016; 20:1039-48.

18. Foresto JS, Melo ES, Costa CRB, Antonini M, Gir E, Reis RK. Adherence to antiretroviral therapy by people living with HIV/AIDS in a municipality of São Paulo. Rev Gaúch Enferm 2017; 38:e63158.

19. Rodrigues PHA. Political challenges facing the consolidation of the Sistema Único de Saúde: a historical approach. Hist Ciênc Saúde-Manguinhos 2014; 21:37-59.

20. Bradley H, Hall HI, Wolitski RJ, Van Handel MM, Stone AE, LaFlam M, et al. Vital signs: HIV diagnosis, care, and treatment among persons living with HIV - United States, 2011. MMWR Morb Mortal Wkly Rep 2014; 63:1113-7.

21. Secretaria de Vigilância em Saúde, Ministério da Saúde. Boletim Epidemiológico Aids e DST - 2014-2015. Ano IV (1). http://www. aids.gov.br/pt-br/centrais-de-conteudos/ biblioteca_busca?search_api_views_fulltex $\mathrm{t}=$ boletim+epidemiologico\&search_api_vie ws_fulltext_1=All\&=Buscar (accessed on 05/ Mar/2017).

22. Grangeiro A, Escuder MML, Castilho EA. A epidemia de AIDS no Brasil e as desigualdades regionais e de oferta de serviço. Cad Saúde Pública 2010; 26:2355-67.
23. Grangeiro A, Escuder MML, Castilho EA. Magnitude and trend of the AIDS epidemic in Brazilian cities, from 2002 to 2006. Rev Saúde Pública 2010; 44:430-40.

24. Grangeiro A, Escuder MML, Menezes PR, Alencar R, Ayres de Castilho E. Late entry into HIV care: estimated impact on AIDS mortality rates in Brazil, 2003-2006. PLoS One 2011; 6:e14585.

25. World Health Organization. Metrics for monitoring the cascade of HIV testing, care and treatment services in Asia and the Pacific. http://www.searo.who.int/entity/hiv/hiv_ metrics.pdf. (accessed on 14/Sep/2017).

26. Perlman DC, Jordan AE, Nash D. Conceptualizing care continua: lessons from HIV, hepatitis $\mathrm{C}$ virus, tuberculosis and implications for the development of improved care and prevention continua. Front Public Health 2017; 4:296.

27. Cesar C, Blugerman G, Valiente JA, Rebeiro P, Sued O, Fink V, et al. The HIV care cascade in Buenos Aires, Argentina: results in a tertiary referral hospital. Rev Panam Salud Pública 2016; 40:448-54.

28. Muth S, Len A, Evans JL, Phou M, Chhit S, Neak Y, et al. HIV treatment cascade among female entertainment and sex workers in Cambodia: impact of amphetamine use and an HIV prevention program. Addict Sci Clin Pract 2017; 12:e20.

29. Alvarez-Uria G, Pakam R, Midde M, Naik PK. Entry, retention, and virological suppression in an HIV cohort study in India: description of the cascade of care and implications for reducing HIV-related mortality in low- and middleincome countries. Interdiscip Perspect Infect Dis 2013; 2013:e384805.

30. Morrow C, Munro A, Wilke M, Stark R, Wood R. Remote sensing of HIV care programmes using centrally collected laboratory results: can we monitor ART programme effectiveness? S Afr Med J 2012; 102:501-5. 


\section{Resumo}

A cascata de cuidados para pessoas vivendo com a infecção pelo HIV (PVHIV) representa os passos no diagnóstico, vínculo e retenção em tratamento, assim como, no fornecimento e resultado da terapia antirretroviral combinada (TARVc). O estudo teve como objetivo avaliar as taxas relativas à retenção em atendimento, uso de TARVc e supressão da carga viral em PVHIV atendidas em uma rede pública de saúde. Através do Sistema de Controle de Exames Laboratoriais (SISCEL), os dados foram coletados retrospectivamente, referentes às PVHIV de 116 municípios no Estado do Paraná, Sul do Brasil, atendidas entre 2012 e 2015. O número de PVHIV vinculadas ao atendimento aumentou em 22,5\% entre 2012 e 2015 (de 4.106 para 5.030 indivíduos). A proporção de PVHIV retidas no atendimento mostrou uma tendência de estabilização, em torno de 81,7-86,9\%. O uso de TARVc aumentou a cada ano, chegando a 90,3\% das PVHIV retidas em atendimento. A supressão da carga viral foi alcançada por $72,8 \%$ dos pacientes em uso de TARVc e em 57,1\% daqueles vinculados ao atendimento. A retenção no atendimento e a supressão da carga viral foram mais frequentes em PVHIV mais velhas e em pacientes residentes em municípios de porte médio. Em conclusão, o estudo mostrou um nível elevado de retenção em atendimento e de supressão da carga viral na vigência do uso de $T A R V c$, além de enfatizar que os esforços atuais de tratamento das PVHIV ainda são um desafio para as instituições de saúde pública, podendo ajudar a identificar passos para melhorar a cascata de cuidados em HIV para a população.

HIV; Terapia Antirretroviral de Alta Atividade; Resposta Viral Sustentada

\section{Resumen}

Este trabajo describe los pasos en la diagnosis, vinculación y retención en el cuidado, así como la provisión y éxito de la terapia antirretroviral combinada (cART por sus siglas en inglés) para personas que viven con una infección de VIH (PLHIV por sus siglas en inglés). El objetivo de este estudio fue evaluar las tasas en relación con la retención en el cuidado, terapia antirretroviral combinada $y$ carga viral eliminada de las personas que viven con una infección de VIH, y reciben atención en la red pública de salud brasileña. Los datos de PLHIV procedieron de 116 ciudades de Paraná, sur de Brasil, desde 2012 a 2015, se recogieron retrospectivamente a través del Sistema de Control de Exámenes de Laboratorio (SISCEL). El número de PLHIV informado con necesidad de cuidados se incrementó un 22,5\% de 2012 a 2015 (de 4.106 a 5.030 individuos). La proporción de PLHIV que fue constante en el cuidado mostró una tendencia hacia la estabilización de alrededor de un 81,7 a un 86,9\%. Cada año, el uso del cART se incrementó hasta un 90,3\% en el caso de PLHIV que fueron constantes en sus cuidados. La eliminación de la carga viral se consiguió en un 72,8\% de los pacientes con cART y en un 57,1\% por parte de aquellos vinculados a cuidados. La constancia en el cuidado y la eliminación de la carga viral en VIH eran más factibles de producirse en PLHIV más viejas que en las jóvenes; de igual forma, los pacientes que vivían en ciudades de tamaño medio eran más susceptibles hacia estos factores que en ciudades más grandes o pequeñas. Como conclusión, el estudio mostró un alto nivel de constancia en el cuidado y la eliminación de carga viral del HIV con cART, asimismo enfatizó que los actuales esfuerzos para tratar a las PLHIV ya infectadas continuaba siendo un desafío para nuestras instituciones públicas de salud y quizás podría contribuir a resaltar los pasos necesarios hacia la mejora de la serie de cuidados en VIH sobre nuestra población.

VIH; Terapia Antirretroviral Altamente Activa; Respuesta Virológica Sostenida
Submitted on 28/Feb/2018

Final version resubmitted on 05/Jun/2018

Approved on 05/Jul/2018 